Research Article

\title{
The Effectiveness of an AI-Enabled Program for Developing Awareness of Citizenship Scientific Values
}

\author{
Halah Alamodi $\mathbb{D}^{1}$ and Najah Arafat $\mathbb{D}^{2}$ \\ ${ }^{1}$ Scientific Education, College of Education, Umm Al-Qura University, Makkah 21955, Saudi Arabia \\ ${ }^{2}$ Scientific Education, Faculty of Education, Mansoura University, Mansoura, Egypt \\ Correspondence should be addressed to Halah Alamodi; hsbaqadiramodi@uqu.edu.sa
}

Received 18 August 2021; Revised 13 September 2021; Accepted 25 September 2021; Published 12 October 2021

Academic Editor: Fazlullah Khan

Copyright (C) 2021 Halah Alamodi and Najah Arafat. This is an open access article distributed under the Creative Commons Attribution License, which permits unrestricted use, distribution, and reproduction in any medium, provided the original work is properly cited.

\begin{abstract}
The present study aims to explore the effectiveness of a proposed AI-enabled program for developing preservice teachers' awareness of citizenship scientific values in light of Saudi Vision 2030. The study utilized the quasi-experimental approach (onegroup design) by testing and identifying the effectiveness of the proposed design in developing awareness of citizenship scientific values among preservice teachers at Umm Al-Qura University. An eleven-domain questionnaire was developed and applied to 60 preservice teachers at Umm Al-Qura University, Saudi Arabia. The results showed that awareness of citizenship scientific values did not achieve the sufficiency level of $85 \%$. An eleven-session program was designed. The study concluded that there were statistically significant differences in the participants' mean scores in the pretest and posttest of the scale of the awareness of citizenship scientific values, favoring the posttest. The proposed program proved effective in developing the participants' awareness of citizenship scientific values.
\end{abstract}

\section{Introduction}

Currently, the scientific and technological progress, globalization, and the evolving challenges have imposed some negative effects on communities. Such global challenges have created a social reality with certain values and criteria. Therefore, educational institutions should maintain citizenship values to avoid risks, achieve objectives, develop curricula, and provide effective teacher preparation. Citizenship is a set of positive values that functionally reflects the behaviors of individuals towards society, namely, loyalty to the homeland, commitment to social standards, and a sense of moral responsibility to the society [1]. Citizenship values are effective behavioral guidelines, including loyalty, political awareness, tolerance, respect for the other opinion, teamwork, and subvalues [2].

Scientific values are those that present issues and topics of science that lead the individuals' behavior, such as rationality and acceptance of matters that help in social development and address global challenges $[3,4]$.
An informed citizenry is not sufficient. The desired citizenry also needs to be participatory, hence allowing citizens to play an active role in the resolving of issues within the society [5].

Values play a great role in peoples' behaviors. These universal values help achieve a social dominance; this allows people to think socially according to these universal values [6].

Citizenship scientific values are the common norms and judgments among society members that express their love and pride in the country, exercising their rights and fulfilling their duties. Therefore, developing citizenship scientific values is an important and effective aim to be achieved by teachers. This helps learners make better decisions, acquire long-life learning skills, develop creative thinking skills, and enhance social and environmental responsibility. Many studies stressed the importance of the teacher's role. For example, Son [7] concluded that students' attitudes towards citizenship are based on the type of teacher who guides the student to the concepts and values of citizenship education. 
Alqahtany [8] revealed the obstacles of exercising citizenship values, including inadequate university education environment to the practice of citizenship values. Mhlauli [9] recommended teacher preparation in citizenship education to achieve the national aspirations of social harmony, unity, and nation building. Biyekenova et al. [10] reported that the development of the system of values in young people is affected by the multicultural society. The data of this study showed the vector of the development of values in youth. This enables predicting the further development of the system of values and integrating said system into the respective world system while preserving the national identity. Moreover, many studies, such as El Takach and Ayoubi [11], Smith et al. [12], and Watfa and Alsharee [13], reported the need to develop programs for citizen development.

Symposia and conferences (e.g., the final report of the symposium on education and citizenship building, 2011; conference of the national unity: Fundamentals and values, [14]) recommended paying attention to citizenship values, methods of activation, and consolidating the culture of citizenship among learners through curricula. In scientific values, Al-Harbi [15], Al-Khalifa [16], Alotaibi [3], Alqahtany [8], and Saeed [17] recommended that the curricula should contain scientific values. They also recommended studying the global issues and problems and achieving interaction between the curricula of science and citizenship.

Citizens need to understand the ongoing nature of science, the way in which evidence constrains it, but also the way in which different interpretations of the evidence are also likely. With this understanding, productive and respectful engagement between scientists and the public becomes possible.

Learners are encouraged to analyze real-life issues critically and helping them to try to find possible solutions in a creative and innovative way and to be able to set assumptions this could all be done through global citizenship education [4].

In order to help develop the citizen science, there should be training of the citizen at all ages and in the different fields, such as humanities, law, education, social sciences, and ethics as well as natural sciences and engineering. This can also help find specific programs for citizen science [18].

Therefore, education should help in emphasizing the role the students can play in both the science and the values elements that inform decision-making processes [19].

The teachers should aim to help the students to understand the values presented to them and to reflect on them by showing them how to apply it in their daily life [20].

Because of the importance of citizenship scientific values, they are covered by the domains and objectives of the Saudi vision 2030 to "build a vibrant society with strong values, rich environment, and strong structure." It contained many orientations, such as pride in national identity, living a healthy life, improving healthcare, and promoting prevention against health risks. It also stresses the integration of the roles of the individual, society, and institutions with health providers to ensure providing care according to the best practices, building the personality of children, social interaction, supporting flexibility, assuming responsibility in life, business, and community, as well as improving the work environment. The objectives of the vision relate to the development of education focus on consolidating positive values, building independent personality, providing the necessary knowledge and skills for the labor market, promoting university student participation in education, and their role in promoting national values and identity.

The coming sections highlight the research problem, questions, objectives, significance, and limits. Following this, the research hypotheses, conceptual framework, and literature review are provided. Moreover, the research methodology, procedures, and the developed proposed program are explained. Next, the result section and its related discussion are presented. Lastly, the paper is concluded by pointing out the recommendations and conclusion.

\section{Research Problem}

The educational literature illustrated the shortage of developing, implementing, and promoting citizenship values among students because of the lack of awareness among teachers in these values. Thus, further studies should be conducted to activate the role of educational institutions in developing citizenship values among preservice teachers. Almaliki [21] reported that courses contain adequate values of citizenship, but their activation requires taking all the necessary measures for the activation of teacher preparation in delivering the concepts and values of citizenship. Alazmi and Alramedi [22], Alghamdi [23], and Mhlauli [9] showed that teachers view citizenship in many ways as national identity, active participation, collective responsibility, and self-reliance.

Authors are interested in citizenship scientific values because of the scientific and technological revolution and openness to Western cultures. Teachers have reconsidered their knowledge because they cannot exercise their original values [16]. The weak role of the university professor in developing citizenship values, especially loyalty, belonging, tolerance, respecting others, political awareness, and volunteer teamwork [24].

Alshamany and Saad [25] concluded students' low level of awareness of the components and elements of national identity. Alahmadi [26] revealed students' poor knowledge of educational issues on global citizenship. Students' attitude towards the issues of global citizenship was highly positive.

Alqahtany [8] showed that citizenship values were rated high and very high in the cognitive and emotional aspects but were rated low in the behavioral aspect. Mhlauli [9] illustrated that the teachers of social studies have various perceptions about citizenship. Moreover, citizenship education in Botswana is based on multiple perspectives with no clear plan.

Garcia, Jacott, and Rico [27] argued that students have a traditional attitude towards global citizenship and recommended developing a cosmopolitan perspective on the promotion of social justice and human rights. Alkhawaldeh [2] indicated that the level of the faculty member in developing citizenship values was average in all domains. Radwan, AlZboon, and AlZboon [28] illustrated that 
students suffer from a low level of citizenship values. The authors recommended activating the role of educational institutions and media in promoting the values among students.

In sum, many studies reported their low level among students and teachers, as well as the need to prepare programs for the development of citizenship scientific values.

2.1. Research Questions. The present study seeks to answer the following major question.

What is the effectiveness of a proposed program for developing preservice teachers' awareness of citizenship scientific values in light of Saudi Vision 2030?

It is divided into the following minor questions:

(1) What citizenship scientific values should be available among preservice teachers in light of Saudi Vision 2030 ?

(2) What is the level of the awareness of citizenship scientific values among preservice teachers in light of Saudi Vision 2030?

(3) What is the proposed program for developing preservice teachers' awareness of citizenship scientific values in light of Saudi Vision 2030?

(4) What is the effectiveness of the proposed program for developing preservice teachers' awareness of citizenship scientific values in light of Saudi Vision 2030 ?

2.2. Research Aim and Objectives. The present study aims to measure the effectiveness of a proposed program for developing preservice teachers' awareness of citizenship scientific values in light of Saudi Vision 2030.

To reach the main aim, the following four objectives should be achieved:

(1) Define citizenship scientific values that should be available among preservice teachers in light of Saudi Vision 2030.

(2) Define the level of the awareness of citizenship scientific values among preservice teachers in light of Saudi Vision 2030.

(3) Make a proposed program for developing preservice teachers' awareness of citizenship scientific values in light of Saudi Vision 2030.

(4) Identify the effectiveness of the proposed program for developing preservice teachers' awareness of citizenship scientific values in light of Saudi Vision 2030.

\subsection{Research Significance}

(1) Achieve the global trends by giving universities a major role in consolidating the positive values in children and providing education that builds personality.
(2) Build personality and guide the behavior and practices towards the achievement of good citizenship.

(3) Utilize the methods, practices, and programs to be provided to preservice teachers to raise awareness of citizenship scientific values. The results may benefit the officials and staff of the teacher preparation programs in identifying the aspects of this desired global vision, guiding policies, and making and achieving plans.

\subsection{Research Limits}

(1) Topic limits were as follows: citizenship scientific values defined in light of Saudi Vision 2030. The program can be generalized worldwide.

(2) Spatial limits were as follows: preservice teachers at Umm Al-Qura University. The program can be generalized on female teachers worldwide.

(3) Human limits were as follows: preservice teachers (chemistry, physics, and biology) at the eighth level and the senior students who are about to start the teacher preparation programs. The program can be applied to all university students.

2.5. Research Hypotheses. There are statistically significant differences at the level of $\leq 0.05$ in the participants' mean scores in the pretest and posttest of the scale of the awareness of citizenship scientific values, favoring the posttest.

\subsubsection{Definition of terms}

Program. It is a set of experiences and attitudes related to citizenship scientific values to be developed among preservice teachers in light of Saudi Vision 2030.

Scientific Values. They are mental and emotional judgments related to science and its issues among preservice teachers while handling scientific situations and experiences. Preservice teachers form them towards the scientific issues and problems they encounter and interact with. They are clear in their interests, attitudes, and behaviors.

Citizenship. It is a set of principles governing the relationship of preservice teachers to their homeland to maintain its wealth and belonging and achieve objectives because they feel responsibilities towards it and participate in building effectively and actively.

Citizenship Scientific Values. They are a set of principles and ideals adopted by preservice teachers. They help the preservice teachers judge their behaviors that belonging and loyalty and can be developed according to Saudi Vision 2030. They include health values, critical thinking skills, making evidence-based judgments, research skills, curiosity, information assessment, research and discussion of controversial issues, respect for the views of others, taking 
responsibility, decision-making, and handling information and communication. They are measured in the present study by the scores on the developed scale of the awareness of citizenship scientific values.

Saudi Vision 2030. The national Saudi vision developed by the Council of Economic and Development Affairs and approved by the Council of Ministers. It includes economic, social, and development programs aiming to achieve a promising future in all fields through three main themes, namely, a vibrant society, a thriving economy, and an ambitious nation.

\subsection{Conceptual Framework and Literature Review}

2.6.1. Citizenship Scientific Values. The scientific values relate to the issues and topics of science that act as guides of the individual behavior towards them. For instance, a person adopts rationality in situations that require acting out of his conviction and believing in importance and full emotional acceptance [3]. Accordingly, they include norms and mental regulations, which govern the behaviors and actions of the individuals in handling and interacting with the scientific, technological, and environmental phenomena. They are based on religious, cultural, social, and scientific fundamentals and are acquired by the various community institutions, curricula, and behaviors.

They can be developed among learners using various methods. According to the National Center for Improving Science [29]. They include the following:

(1) Value analysis by analyzing community issues and examining the relevant values through current events and role-playing

(2) Value illustration: the value-related problem that is presented and discussed with the learner.

(3) Integration method: integrating the cognitive and the emotional aspects of the value.

(4) Behavior modification: modifying behavior using various reinforcement methods.

Many studies addressed evaluating the content of the book based on scientific values. Saeed [17] revealed the poor content of biology schoolbook concerning most scientific and ethical values. The study proved the effectiveness of teaching two adjusted units based on ethical and scientific values in providing high school students all ethical and scientific values. Alqahtany [30] reported that curiosity and appreciation of science were ranked first in the book of physics. In addition, Alotaibi [3] showed that citizenship scientific values in the schoolbooks of Science for middle school were rated intermediate.

Citizenship values are effective behavioral guidelines, including loyalty, belonging, political awareness, tolerance, respect for the other opinion, teamwork, community problem-solving, critical thinking, and research skills [2, 31]. It is the norms that the students use to evaluate their behaviors, reflected in national loyalty and belonging, political participation, voluntary work, understanding the concepts of democracy, and tolerating others [32]. In short, citizenship is a set of principles that govern the individualhomeland relationship based on the commitment to the national values. One takes responsibility towards the country and builds it effectively and actively to achieve Saudi Vision 2030.

Citizenship scientific values are the norms used to judge the validity of behaviors that reflect loyalty and belonging, as well as understanding the national identity. Some mechanisms may help promote citizenship scientific values among learners, such as the practice of a real activity of community service, voluntary work with civil associations, and invitation of students to volunteer in a service educational project during holidays. Such projects improve the ability of youth to communicate and contact successfully with others [33].

Elsayed and Ismail [34] concluded that the university does not participate effectively in raising the awareness of students of the principles of citizenship. Thus, its role should be maintained and promoted. Al-Khalifa [16] illustrated that solving environmental problems, patience, making studied judgments, scientific curiosity, utilizing scientific thinking skills, appreciating science, respect for scholars, scientific integrity, and ethics were ranked the highest among the students of the colleges of applied sciences. Moreover, the students inadequately practice the behaviors of citizenship scientific values in the scale. Althbyta and Hussein [1] reported the generally high level of citizenship among the students of the University of Tabuk concerning loyalty, commitment to social norms, and taking ethical responsibility to society.

\subsubsection{Domains of Citizenship Scientific Values in Light of} Saudi Vision 2030. Saudi Vision 2030 is based on 3 themes, that is, a vibrant society, a thriving economy, and an ambitious nation, which interacts and integrates to achieve the objectives of Saudi Arabia. Saudi Vision 2030 aims to prepare, develop, and vocationally qualify the teacher in a manner that meets the requirements of the twenty-first century to keep up with the intellectual, cognitive, technological, and industrial developments.

Analyzing Saudi Vision 2030 and reviewing the literature on citizenship scientific values, such as El Takach and Ayoubi [11], Newman et al. [35], and Smith et al. [12], showed some citizenship scientific values that should be developed among preservice teachers to achieve Saudi Vision 2030:

(1) Health values: maintaining and continuity of health are the responsibility of every member in the community by adhering to sound health traditions defined by the educational objectives. Community production and development are based on acquiring and practicing health values.

(2) Critical thinking: individuals should be critical thinkers because critical thinking triggers curiosity, research, and inquiry to widen the mental horizons for students and enrich their life experiences. It is governed by the rules of logic and analysis, in which 
individuals make assumptions, interpretations, discussions, and inference [36].

(3) Making evidence-based judgments: an important thinking pattern was adopted when handling many complex situations and stimuli by covering information, examining issues based on evidence, comparing incidents and news, and conclusion [37].

(4) Research skills: They are a popular prerequisite applied in all spheres of life on campus or off campus. They help handle future changes and problems. Scientific research is it is a systemic and controlled measure that searches hypotheses of the relations between the events and phenomena, requires objective and accurate measures to achieve replicable results, adds to the systemic knowledge, and helps to solve problems [38].

(5) Curiosity: it aims to get information on a topic or idea through an exploratory behavior. That is, a person looks for new information by approaching new and controversial problems, situations, and stimuli by raising questions and making alternatives creatively [39].

(6) Information assessment: citizenship scientific values relate to information assessment, including judging information and ideas scientifically, validating information through research, validating information to define the appropriate alternative, using scientific references to verify information, making sound judgments, and not accepting ideas unless there is evidence $[37,40,41]$.

(7) Research and discussion of controversial issues: basic skills, research, and discussing controversial issues among students in all stages should be developed by triggering curiosity and enhancing analysis and interpretation. Alaskhqar [42] illustrated that joining scientific debate requires making data meaningful, discussing natural phenomena, interpretation based on scientific evidence and logical inference, and criticism of the perspective of others.

(8) Respect for the views of others: it is a means to build a new form of relations and a sound manner to solving all issues. Dialog keeps effective communication and deepens democracy among all members of the community [43].

(9) Taking responsibility: if people take responsibility and demonstrate cooperation, altruism, and love and help of others, they can help promote the community. By taking responsibility, we choose behavior that meets our and others' needs. According to Saada [37], taking responsibility is a skill of building self-motivation and self-reliance.

(10) Decision-making: it is a situation, opinion, or judgment taken after consideration, thinking, and considering evidence [44]. The skills of decision- making suggest choosing the appropriate available alternative concerning various scientific issues that require thinking [45].

(11) Handling information and communication: social media are significant for communication and exchange of information. Therefore, secure policies should be adopted to ensure the appropriate ethical practice concerning privacy. Awareness should be raised that the exchange of information via social media, which is the responsibility of users concerning ensuring their validity before exchange or posting. Moreover, no information about others should be posted before the consent of the owner [46].

To conclude, the development of citizenship scientific values is important because they improve the behaviors, national identity, belonging, and taking responsibility among community members. Thus, they help achieve the Global Trends Goals and Saudi Vision 2030.

2.7. Research Methodology and Procedures. IThe study adopted the quasi-experimental approach (one-group design) by testing and identifying the effectiveness of the proposed design in developing awareness of citizenship scientific values among preservice teachers at Umm Al-Qura University.

2.8. Sample. The sample of the study included sixty preservice science teachers from different scientific majors participating in the study (chemistry, physics, and biology) at the eighth level and the senior students who are about to start the teacher preparation programs.

\subsection{Procedures}

(1) The list of citizenship scientific values was developed A list of citizenship scientific values was developed by the following:

(1) Reviewing the literature on citizenship scientific values

(2) Reviewing and analyzing the Saudi Vision 2030

(3) Developing a preliminary form of citizenship scientific values in the form of a questionnaire

(4) Presenting the questionnaire to a group of specialized reviewers. In its final form, the questionnaire comprised eleven domains, that is, health values, critical thinking skills, making evidence-based judgments, research skills, curiosity, information assessment, research and discussion of controversial issues, respect for the views of others, taking responsibility, decisionmaking, and handling information and communication

(2) The scale of citizenship scientific values was developed 
2.10. Tools. The scale of citizenship scientific values aimed to define the level of citizenship scientific values among preservice teachers in light of Saudi Vision 2030. After reviewing the relevant literature, a list of citizenship scientific values was developed as the scale domains. A 69-item questionnaire was formulated. It is answered according to a three-graded rubric: (3) high, (2) moderate, and (1) low. A participant selects a response that expresses her behavior.

Regarding validity, the preliminary form of the scale was presented to a group of reviewers. The reviewers approved the items and reported the appropriateness of the scale to the undergraduate level.

The scale was pretested to a pilot sample of 20 preservice teachers to estimate the validity and reliability of the scale.

Regarding internal consistency, the correlation coefficients of items and the total score of the domain were calculated (see Table 1).

Table 1 illustrates that all correlation coefficients are positive and significant at the level of 0.01 . They vary between the item and the domain from 0.500 to 0.885 .

The correlation coefficients of items and the scale total score were calculated (see Table 2).

Table 2 shows that all correlation coefficients are positive and significant at the level of 0.01 . They vary between the item and the domain from 0.525 to 0.887 .

The reliability of the scale was calculated using Cronbach's alpha. The results are displayed in Table 3.

Table 3 illustrates the values of the reliability of the domains rating (0.654-0.863). The total value of the scale reliability estimates 0.816 . These values are high and statistically significant.

The self-validity of the scale was estimated using the following equation:

coefficient of self - validity $\sqrt{\text { reliability coefficient }}=\sqrt{0.816}=0.903$.

This suggests a high level of self-validity.

The final form of the scale is given in Table 4. In its final form, the scale comprises 69 items $\left({ }^{*}\right)$, as shown in Table 4 .

As in Table 4, the scale was graded according to (3) agree, (2) neutral, and (1) disagree for the positive items and vice versa for the negative ones. The maximum, minimum, and neutral scores of the scale are 207,69, and 138, respectively.

\subsection{Developing the Proposed Program in Light of Saudi Vision 2030}

2.11.1. Defining the Program Philosophy. The program was developed after reviewing international programs, design principles, objectives, contents, activities, strategies, instruction methods, evaluation methods, and benefits. Moreover, Saudi Vision 2030 was analyzed, and the implications of values and national identity were defined. The vision focuses on the following:

(1) A vibrant and ambitious society with well-established values, a rich environment, and a solid structure was built. It covers many orientations, such as pride in national identity, living a healthy life, enhancing healthcare, and promoting prevention against health risks. It also stresses the integration of the roles of the individual, society, and institutions with health providers to ensure providing care according to the best practices, building the personality of children, social interaction, supporting flexibility, assuming responsibility in life, business, and community, and improving the work environment.

(2) The vision aims to develop university education by consolidating positive values, building an independent personality.

(3) It provides citizens with the necessary knowledge and skills for the labor market.

(4) It promotes university students' participation in education and their role in promoting national values and identity.

2.11.2. The General Objective of the Training Program. It aims to develop preservice teachers' awareness of citizenship scientific values in light of Saudi Vision 2030.

2.11.3. Detailed Objectives of the Training Program. In light of the results of testing the scale of the awareness of citizenship scientific values and highlighting the shortcomings of citizenship scientific values among preservice teachers, a set of objectives was defined.

2.11.4. Contents of the Program. The program contains 11 domains of citizenship scientific values. Table 5 illustrates the timeframe of the sessions of the proposed program for developing preservice teachers' awareness of citizenship scientific values in light of Saudi Vision 2030.

2.11.5. Educational Aids and Activities. The study used worksheets, oral discussions, a board, a computer, CDs, and a data show.

2.11.6. Implementation Strategies. Implementation strategies included collaborative learning, dialog and discussion, brainstorming, lecture, and self-learning.

2.11.7. The Final Form of the Proposed Program. The proposed training program was presented to a group of reviewers for evaluation and giving opinions. After making modifications, the final form was obtained.

\subsubsection{Testing}

(1) Pretest of the scale of citizenship scientific values: it was pretested to the preservice teachers before implementing the proposed program on 4/7/2019. Then, the responses were graded. 
TABle 1: Correlation coefficients between each item and the domain total score $(N=20)$.

\begin{tabular}{|c|c|c|}
\hline Domain & Item & Correlation coefficient \\
\hline \multirow{7}{*}{ Health values } & 1 & $0.555^{* *}$ \\
\hline & 2 & $0.636^{* *}$ \\
\hline & 3 & $0.568^{* *}$ \\
\hline & 4 & $0.761^{* *}$ \\
\hline & 5 & $0.557^{* *}$ \\
\hline & 6 & $0.679^{* *}$ \\
\hline & 7 & $0.578^{* *}$ \\
\hline \multirow{6}{*}{ Making judgments } & 1 & $0.688^{* *}$ \\
\hline & 2 & $0.744^{* *}$ \\
\hline & 3 & $0.762^{* *}$ \\
\hline & 4 & $0.505^{* *}$ \\
\hline & 5 & $0.758^{* *}$ \\
\hline & 6 & $0.751^{* *}$ \\
\hline \multirow{6}{*}{ Critical thinking } & 1 & $0.697^{* *}$ \\
\hline & 2 & $0.638^{* *}$ \\
\hline & 3 & $0.558^{* *}$ \\
\hline & 4 & $0.576^{* *}$ \\
\hline & 5 & $0.664^{* *}$ \\
\hline & 6 & $0.502^{* *}$ \\
\hline \multirow{6}{*}{ Research skills } & 1 & $0.549^{* *}$ \\
\hline & 2 & $0.593^{* *}$ \\
\hline & 3 & $0.685^{* *}$ \\
\hline & 4 & $0.709^{* *}$ \\
\hline & 5 & $0.741^{* *}$ \\
\hline & 6 & $0.575^{* *}$ \\
\hline \multirow{7}{*}{ Curiosity } & 1 & $0.510^{* *}$ \\
\hline & 2 & $0.503^{* *}$ \\
\hline & 3 & $0.694^{* *}$ \\
\hline & 4 & $0.525^{* *}$ \\
\hline & 5 & $0.524^{* *}$ \\
\hline & 6 & $0.535^{* *}$ \\
\hline & 7 & $0.885^{* *}$ \\
\hline \multirow{5}{*}{ Information assessment } & 1 & $0.545^{* *}$ \\
\hline & 2 & $0.526^{* *}$ \\
\hline & 3 & $0.788^{* *}$ \\
\hline & 4 & $0.735^{* *}$ \\
\hline & 5 & $0.670^{* *}$ \\
\hline \multirow{9}{*}{ Discussing issues } & 1 & $0.576^{* *}$ \\
\hline & 2 & $0.541^{* *}$ \\
\hline & 3 & $0.777^{* *}$ \\
\hline & 4 & $0.598^{* *}$ \\
\hline & 5 & $0.582^{* *}$ \\
\hline & 6 & $0.598^{* *}$ \\
\hline & 7 & $0.598^{* *}$ \\
\hline & 8 & $0.802^{* *}$ \\
\hline & 9 & $0.596^{* *}$ \\
\hline \multirow{6}{*}{ Respect for the views of others } & 1 & $0.568^{* *}$ \\
\hline & 2 & $0.560^{* *}$ \\
\hline & 3 & $0.588^{* *}$ \\
\hline & 4 & $0.691^{* *}$ \\
\hline & 5 & $0.614^{* *}$ \\
\hline & 6 & $0.612^{* *}$ \\
\hline \multirow{6}{*}{ Taking responsibility } & 1 & $0.692^{* *}$ \\
\hline & 2 & $0.521^{* *}$ \\
\hline & 3 & $0.585^{* *}$ \\
\hline & 4 & $0.500^{* *}$ \\
\hline & 5 & $0.579^{* *}$ \\
\hline & 6 & $0.674^{* *}$ \\
\hline
\end{tabular}

TABle 1: Continued.

\begin{tabular}{lcc}
\hline Domain & Item & Correlation coefficient \\
\hline \hline \multirow{3}{*}{ Decision-making } & 1 & $0.549^{* *}$ \\
& 2 & $0.596^{* *}$ \\
& 3 & $0.776^{* *}$ \\
& 4 & $0.632^{* *}$ \\
Handling information and & 5 & $0.745^{* *}$ \\
communication & 1 & $0.678^{* *}$ \\
& 2 & $0.791^{* *}$ \\
& 3 & $0.665^{* *}$ \\
& 4 & $0.503^{* *}$ \\
& 5 & $0.719^{* *}$ \\
\hline
\end{tabular}

${ }^{* *}$ Significance at the level of 0.01 .

(2) Testing the proposed program was as follows: the proposed training program was tested over 12 sessions and a 2-hour session weekly. Only the first session was orientation. Testing was from 7/7/2019 to $8 / 9 / 2019$, that is, testing took 10 weeks.

2.11.9. Posttest of the Tool. After testing the program, the scale of citizenship scientific values was posttested on $9 / 9 /$ 2019.

\section{Results and Discussion according to the Limits of the Research}

To answer the second question, arithmetic means, standard deviations, and relative importance of the domains of the scale of the awareness of citizenship scientific values were calculated. The scale was compared to the sufficiency level of $85 \%$ of the values. The results are shown in Table 6.

Table 6 illustrates that the level of the awareness of citizenship scientific values among preservice teachers is less than the sufficiency level of 85 .

This finding may be due to the lack of the domains of citizenship scientific values among the preservice teachers. They are not adequately covered in the courses, and poor attention is given to disseminating these values among the participants. Moreover, the participants focus on the cognitive aspect of courses, and they are keen on passing tests with high scores. The traditional methods do not allow students to develop values that include issues such as health values, critical thinking, making evidencebased judgments, research skills, curiosity, information assessment, research and discussion of controversial issues, respect for the views of others, taking responsibility, decision-making, and handling information and communication.

To answer the third question and verify the second hypothesis, the " $T$ " value on the means of differences in the means of scores in the pretest and posttest was calculated, as shown in Table 7.

Table 7 shows statistically significant differences in the means of scores of the pretest and posttest of the scale and 
TABLE 2: Correlation of items and the scale total score.

\begin{tabular}{lccc}
\hline Domain & Correlation coefficient & Domain & Correlation coefficient \\
\hline Health values & $0.684^{* *}$ & Discussing issues & $0.666^{* *}$ \\
Making judgments & $0.634^{* *}$ & Respect for the views of others & $0.614^{* *}$ \\
Critical thinking & $0.802^{* *}$ & Taking responsibility & $0.689^{* *}$ \\
Research skills & $0.525^{* *}$ & Decision-making & $0.783^{* *}$ \\
Curiosity & $0.593^{* *}$ & Handling information and communication & $0.709^{* *}$ \\
Information assessment & $0.887^{* *}$ & & \\
\hline
\end{tabular}

TABLE 3: Cronbach's alpha of the domains and the scale.

\begin{tabular}{lcc}
\hline Domain & No. of items & Alpha coefficient (reliability) \\
\hline Health values & 7 & 0.663 \\
Making judgments & 6 & 0.654 \\
Critical thinking & 6 & 0.804 \\
Research skills & 6 & 0.809 \\
Curiosity & 7 & 0.761 \\
Information assessment & 5 & 0.863 \\
Total score & 69 & 0.816 \\
Discussing issues & 9 & 0.741 \\
Respect for the views of others & 6 & 0.844 \\
Taking responsibility & 6 & 0.662 \\
Decision-making & 5 & 0.659 \\
Handling information and communication & 6 & 0.691 \\
\hline
\end{tabular}

TABLE 4: Domains and items of the scale of the awareness of citizenship scientific values.

\begin{tabular}{|c|c|c|c|c|c|}
\hline & Domain & Positive items & Negative items & No. of items & Percentage \\
\hline 1 & Health values & $1,2,4,7$ & $3,5,6$ & 7 & 10 \\
\hline 2 & Critical thinking skills & $8,9,11$ & $10,12,13$ & 6 & 8.6 \\
\hline 3 & Making evidence-based judgments & $14,15,17,19$ & 16,18 & 6 & 8.6 \\
\hline 4 & Research skills & $20,22,24$ & $21,23,25$ & 6 & 8.6 \\
\hline 5 & Curiosity & $26,28,31,32$ & $27,29,30$ & 7 & 10 \\
\hline 6 & Information assessment & $33,35,36$ & 34,37 & 5 & 7.2 \\
\hline 7 & Research and discussion of controversial issues & $38,39,41,43,44$ & $40,42,45,46$ & 9 & 13 \\
\hline 8 & Respect for the views of others & $47,49,51$ & $48,50,52$ & 6 & 8.6 \\
\hline 9 & Taking responsibility & $53,54,56$ & $55,57,58$ & 6 & 8.6 \\
\hline 10 & Decision-making & $59,60,62$ & 61,63 & 5 & 7.2 \\
\hline \multirow[t]{2}{*}{11} & Handling information and communication & $64,67,69$ & $65,66,68$ & 6 & 8.6 \\
\hline & Total & 69 & & & $100 \%$ \\
\hline
\end{tabular}

TABLE 5: Timeframe of the sessions of the proposed program for developing preservice teachers' awareness of citizenship scientific values in light of Saudi Vision 2030.

\begin{tabular}{lccc}
\hline Training day & Date & Session duration & Topics of the session: \\
One & $7 / 7 / 2019$ & 1 hour & Session I orientation \\
Two & $14 / 7 / 2019$ & 2 hours & Session II health values \\
Three & $21 / 7 / 2019$ & 2 hours & Session II critical thinking skills \\
Four & $28 / 7 / 2019$ & 2 hours & Session IV making evidence-based judgments and information assessment \\
Five & $4 / 8 / 2019$ & 2 hours & Session V research skills \\
Six & $11 / 8 / 2019$ & 2 hours & Session VI curiosity \\
Seven & $18 / 8 / 2019$ & 2 hours & Session VII research and discussion of controversial issues \\
Eight & $25 / 8 / 2019$ & 2 hours & Session VIII respect for the views of others \\
Nine & $1 / 9 / 2019$ & 2 hours & Session IX taking responsibility \\
Ten & $8 / 9 / 2019$ & 2 hours & Session X decision-making \\
& & & Session XI handling information and communication \\
\hline
\end{tabular}


TABLE 6: Arithmetic means, relative importance, and sufficiency level of the means of the scale's domains and total score.

\begin{tabular}{lcccc}
\hline Domains & No. of items & Means & Relative importance (\%) & Sufficiency level (85\%) \\
\hline Health values & 7 & 11.1 & 52.9 & 17.85 \\
Making judgments & 6 & 9.47 & 52.6 & 15.3 \\
Critical thinking & 6 & 9.15 & 50.6 & 15.3 \\
Research skills & 6 & 9.02 & 50.1 & 15.3 \\
Curiosity & 7 & 10.53 & 50.1 & 17.85 \\
Information assessment & 5 & 8.58 & 57.2 & 12.75 \\
Discussing issues & 9 & 14.55 & 53.9 & 22.95 \\
Respect for the views of others & 6 & 9.62 & 53.4 & 15.3 \\
Taking responsibility & 6 & 8.82 & 49 & 15.3 \\
Decision-making & 5 & 8.8 & 58.7 & 12.75 \\
Handling information and communication & 6 & 8.95 & 49.7 & 15.3 \\
Total score & 69 & 108.6 & 37.7 & 175.95 \\
\hline
\end{tabular}

the domains, favoring the posttest. To define the effect of the proposed program on raising awareness of citizenship scientific values among preservice teachers in light of Saudi Vision 2030, (T) value and effect size $\left(\eta^{2}\right)$ were calculated, as shown in Table 8.

Table 8 illustrates that the effect size of the proposed program of raising awareness of citizenship scientific values (domains and total score) among preservice teachers ranged from 0.813 to 0.949 , indicating that $81.3 \%-94.9 \%$ of the variance is caused by the proposed program. This is high effect size. The total effect size of the program was 0.983 , suggesting that $98.3 \%$ of the variance is caused by the program, which is high.

The study results addressed the effectiveness of the programs on developing citizenship in general and citizenship scientific values in particular, and this agreed with the studies done $[1,34,47]$.

To identify the effectiveness of the proposed program than the threshold of Blake's modified gain ratio in developing the awareness of citizenship scientific values among the preservice teachers, the arithmetic means and Blake's modified gain ratio [48] were calculated in the following equation among the participants, as shown in Table 9:

$$
{ }^{*} \eta^{2}=\frac{t^{2}}{t^{2}+d f}
$$

In the case of parametric tests,

$$
\text { Blake's modified gain ratio }=\frac{P-S}{T}+\frac{P-S}{T-S},
$$

where $P$ is the means of the participants' scores in the posttest, $S$ is the means of the participants' scores in the pretest and $T$ is the total score.

Table 9 illustrates the effectiveness of the program rate (1.3), which is acceptable because the threshold of Blake's modified gain ratio is 1.2 .

The results proved the effectiveness of the proposed program in developing citizenship scientific values among the eighth-level students (major: chemistry, physics, and biology) at the College of Applied Sciences in the posttest. This result may be because the program developed in light of Saudi Vision 2030 is characterized by the following:

(1) The comprehensiveness of material that covers the domains of citizenship scientific values simply and clearly. The program developed relevant knowledge, skills, and attitudes among participants.

(2) It developed citizenship scientific values among participants to enhance the participants' understanding of these values and provided them with references during free discussions and answering worksheets. Thus, the level of values has been enhanced during sessions.

(3) Preservice teachers were enthusiastic to participate in the program sessions.

(4) Worksheets were prepared well.

(5) Various and attractive teaching methods increased the interaction of preservice teachers with the program.

(6) The participants received continuous reinforcement throughout the program and feedback at the end of each session.

(7) The teaching aids (presentations, data show, and computer) played a major role in enhancing the motivation of the participants to the program that developed their citizenship scientific values.

(8) The appropriate environment was provided for the program. It was characterized by cooperation, respect for others' opinions, extensive discussions, and exchange of opinions.

(9) The program provided the participants with appropriate information related to citizenship scientific values concerning study and life. It also offered information on how to live a normal life with their rights and duties. It gave authentic examples, applications, and discussions. As a result, the participants had positive attitudes.

(10) The timing of the sessions was defined to fit all participants. The sessions allowed a great deal of 
TABLE 7: Tvalue of the differences of the mean of scores in the pretest and posttest of the scale of the awareness of citizenship scientific values and its domains.

\begin{tabular}{|c|c|c|c|c|c|c|c|}
\hline Domain & Test & Number & Means & Standard deviation & $T$ value & Freedom degree & Significance \\
\hline \multirow{2}{*}{ Health values } & Pretest & 60 & 11.10 & 1.602 & \multirow{2}{*}{-27.3} & \multirow{2}{*}{59} & \multirow{2}{*}{0.01} \\
\hline & Posttest & 60 & 18.95 & 1.863 & & & \\
\hline \multirow{2}{*}{ Making judgments } & Pretest & 60 & 9.47 & 2.119 & \multirow{2}{*}{-20.5} & \multirow{2}{*}{59} & \multirow{2}{*}{0.01} \\
\hline & Posttest & 60 & 16.75 & 1.772 & & & \\
\hline \multirow{2}{*}{ Critical thinking } & Pretest & 60 & 9.15 & 2.185 & \multirow{2}{*}{-22.2} & \multirow{2}{*}{59} & \multirow{2}{*}{0.01} \\
\hline & Posttest & 60 & 16.70 & 1.690 & & & \\
\hline \multirow{2}{*}{ Research skills } & Pretest & 60 & 9.02 & 2.029 & \multirow{2}{*}{-22.2} & \multirow{2}{*}{59} & \multirow{2}{*}{0.01} \\
\hline & Posttest & 60 & 16.85 & 1.755 & & & \\
\hline \multirow{2}{*}{ Curiosity } & Pretest & 60 & 10.53 & 1.741 & \multirow{2}{*}{-33.3} & \multirow{2}{*}{59} & \multirow{2}{*}{0.01} \\
\hline & Posttest & 60 & 20.50 & 1.255 & & & \\
\hline \multirow{2}{*}{ Information assessment } & Pretest & 60 & 8.58 & 2.069 & \multirow{2}{*}{-17.4} & \multirow{2}{*}{59} & \multirow{2}{*}{0.01} \\
\hline & Posttest & 60 & 14.30 & 1.280 & & & \\
\hline \multirow{2}{*}{ Discussing issues } & Pretest & 60 & 14.55 & 2.620 & \multirow{2}{*}{-26.2} & \multirow{2}{*}{59} & \multirow{2}{*}{0.01} \\
\hline & Posttest & 60 & 24.87 & 2.182 & & & \\
\hline \multirow{2}{*}{ Respect for the views of others } & Pretest & 60 & 9.62 & 1.439 & \multirow{2}{*}{-28.2} & \multirow{2}{*}{59} & \multirow{2}{*}{0.01} \\
\hline & Posttest & 60 & 16.95 & 1.545 & & & \\
\hline \multirow{2}{*}{ Taking responsibility } & Pretest & 60 & 8.82 & 1.702 & -284 & 59 & \\
\hline & Posttest & 60 & 17.07 & 1.550 & -28.4 & 59 & 0.01 \\
\hline Decision-making & Pretest & 60 & 8.80 & 2.146 & -160 & 59 & 0.01 \\
\hline & Posttest & 60 & 14.20 & 1.338 & -10.0 & & \\
\hline Handlino information and communication & Pretest & 60 & 8.95 & 1.620 & -251 & 59 & 001 \\
\hline Handing inrormation and communication & Posttest & 60 & 16.65 & 1.783 & & 59 & 0.01 \\
\hline & Pretest & 60 & 108.58 & 9.078 & & 59 & \\
\hline Total score & Posttest & 60 & 193.78 & 7.038 & & 59 & 0.01 \\
\hline
\end{tabular}

TABLE 8: T value and effect size $\left(\eta^{2}\right)$ of the proposed program on raising awareness of citizenship scientific values among preservice teachers.

\begin{tabular}{|c|c|c|c|c|}
\hline Domain & Number $(n)$ & $T$ value & Effect size $\left(\eta^{2 *}\right)$ & Effect size \\
\hline Health values & & -27.3 & 0.927 & High \\
\hline Making judgments & & -20.5 & 0.877 & High \\
\hline Critical thinking & & -22.2 & 0.893 & High \\
\hline Research skills & & -22.2 & 0.893 & High \\
\hline Curiosity & & -33.3 & 0.949 & High \\
\hline Information assessment & & -17.4 & 0.837 & High \\
\hline Discussing issues & 60 & -26.2 & 0.921 & High \\
\hline Respect for the views of others & & -28.2 & 0.931 & High \\
\hline Taking responsibility & & -28.4 & 0.932 & High \\
\hline Decision-making & & -16.0 & 0.813 & High \\
\hline Handling information and communication & & -25.1 & 0.914 & High \\
\hline Total score & & -58.4 & 0.983 & High \\
\hline
\end{tabular}

TABLE 9: Means of the participants' scores on the scale of the awareness of citizenship scientific values and Blake's modified gain ratio.

\begin{tabular}{lcccc}
\hline $\begin{array}{l}\text { Means of the participants' scores in } \\
\text { the pretest }\end{array}$ & $\begin{array}{c}\text { Means of the participants' scores in the } \\
\text { posttest }\end{array}$ & $\begin{array}{c}\text { Maximum } \\
\text { score }\end{array}$ & $\begin{array}{c}\text { Blake's modified gain } \\
\text { ratio }\end{array}$ & $\begin{array}{c}\text { Significance level } \\
108.58\end{array}$ \\
\hline
\end{tabular}

freedom of expression. This helped generate positive ideas about the practice of citizenship scientific values.

The program enhanced the participants' feeling of the importance of citizenship scientific values to promote education quantitatively and qualitatively.
3.1. Recommendations. The researcher sets out a number of recommendations:

Research recommends reformulating and organizing the courses of preparation programs of teachers of science to include topics that develop their citizenship scientific values, developing and reconsidering the pr-university courses of 
science according to citizenship scientific values, training preservice teachers in utilizing citizenship scientific values in the teaching of science subjects, holding seminars and workshops to raise the awareness of preservice teachers of citizenship scientific values, and employing citizenship scientific values in science courses in all stages.

\section{Conclusion}

To conclude, the program was developed according to Saudi Vision 2030. It helped develop some international citizenship scientific values, build an independent national personality, promote participation in education, and enhance the role of the participants in promoting the national identity and values. In other words, the program proved effective in developing citizenship scientific values. Moreover, it surpassed the threshold of Blake's modified gain ratio in developing the awareness of citizenship scientific values. However, one of the challenges that face such research is performing it with larger number of participants and applying it for a longer duration. Future work will include training preservice teachers in the utilization of citizenship scientific values in teaching.

\section{Data Availability}

The data used to support the findings of this study are available from the corresponding author upon request.

\section{Conflicts of Interest}

The authors declare that there are no conflicts of interest regarding the publication of this article.

\section{Acknowledgments}

The authors would like to thank the Deanship of Scientific Research at Umm Al-Qura University for supporting this work under Grant Code 18-EDU-1-03-0001.

\section{References}

[1] M. Althbyta and M. Hussein, "The role of university administration in developing citizenship skills among the students of the University of Tabuk," Taibah University Journal of Educational Sciences, vol. 11, no. 3, pp. 349-356, 2016.

[2] T. Alkhawaldeh, "The role of the faculty member at Jordanian universities in developing citizenship values from the student perspective," Dirasat: Human and Social Sciences, vol. 40, no. 3, pp. 1160-1180, 2013.

[3] W. Alotaibi, "Citizenship scientific values in the schoolbooks of science for the middle school in Saudi Arabia (An analytical study)," Journal of the Faculty of Education-Al-Azhar University, vol. 153, no. 1, pp. 127-177, 2013.

[4] UNESCO, Global Citizenship Education: Preparing Learners for the Challenges of the Twenty-First Century, United Nations Educational, Scientific and Cultural Organization, France, 2014.

[5] T. Chowdhury, J. Holbrook, J. Holbrook, and M. Rannikmäe, "Socioscientific issues within science education and their role in promoting the desired citizenry," Science Education International, vol. 31, no. 2, pp. 203-208, 2020.
[6] J. Hatley, "Universal values as a barrier to the effectiveness of global citizenship education: a multimodal critical discourse analysis," International Journal of Development Education and Global Learning, vol. 11, no. 1, pp. 87-102, 2019.

[7] M. Richardson, "Assessing the assessment of citizenship," Research Papers in Education, vol. 25, no. 4, pp. 457-478, 2010.

[8] A. Alqahtany, Citizenship values among youth and contribution to promoting preventive security, Ph.D. thesis, College of Graduate Studies, Naif Arab University for Security Sciences, KSA, 2010.

[9] M. B. Mhlauli, "Understanding the social studies teachers' experiences: conceptions of citizenship in Botswana," International Journal of Scientific Research in Education, vol. 4, no. 3\&4, pp. 165-180, 2011.

[10] N. Biyekenova, G. Abdiraiymova, G. Kenzhakimova, Z. Shaukenova, and Z. \&Senuk, "Value system of students of the republic of Kazakhstan as a special social and cultural group," International Journal of Environmental \& Science Education, vol. 1, no. 9, pp. 2481-2494, 2016.

[11] S. El Takach and Z. Ayoubi, "Science literacy for citizenship: bridging the gap. A Delphi study of Arab and Lebanese experts," The Eurasia Proceedings of Educational \& Social Sciences, vol. 11, pp. 43-62, 2018.

[12] E. Smith, S. Parks, S. Gunashekar, C. Lichten, A. Knack, and C. Manville, The Citizen's Role and Contribution to Research, RAND Corporation, Santa Monica, CA, 2017.

[13] A. Watfa and S. Alsharee, "The role of Kuwait University in promoting citizenship values among students: a student perspective," The Sociological Association in Sharjah, vol. 35, no. 140, pp. 99-155, 2018.

[14] Harbi Al-Imam Mohammad IBN Saud Islamic University, "Conference of the national unity: fundamentals and values," Riyadh: Al-Imam Mohammad IBNn Saud Islamic University, KSA, 2013.

[15] A. Al-Harbi, The importance of the role of science teachers in developing the scientific values among the third-year high school students in Saudi Arabia, Ph.D. thesis, Umm Al-Qura University, Makkah, 2010.

[16] F. Al-Khalifa, "Some behaviors of promoting and the reality of practicing citizenship scientific values among the students of the colleges of applied sciences in Oman," in Proceedings of the the Third Student Conference at Nizwa University "Promotion of Citizenship Values”, pp. 1-28, Nizwa University, Oman, 2011.

[17] N. Saeed, "The role of the schoolbooks of biology in promoting the scientific and ethical values among the secondary school students," Journal of the Faculty of Education-Mansoura University, vol. 78, no. 1, pp. 253-285, 2012.

[18] C. Gaffield, P. Corvol, J. Hackar, G. Parisi, and M. Mcnutt, Citizen Science in the Internet Era, Summit of the G7 Science Academies, France, 2019.

[19] C. Cooper, "Links and distinctions among citizenship, science, and citizen science," Democracy \& Education, vol. 20, no. 2, pp. 1-4, 2012.

[20] K. Komalasari and D. Saripudin, "Value-based interactive multimedia development through integrated practice for the formation of students' character," Turkish Online Journal of Educational Technology, vol. 16, no. 4, pp. 179-186, 2017.

[21] A. Almaliki, "The role of teaching national education in developing citizenship values among primary stage students: the perspective of the teachers of national education in Al Lith Governorate," M.A. thesis, College of Education, Umm AlQura University, Makkah, 2009. 
[22] M. Alazmi and K. Alramedi, "The role of teachers in developing the national values among high school students in Kuwait," The Educational Journal- Kuwait University, vol. 25, no. 99, pp. 13-71, 2011.

[23] A. Alghamdi, "Citizenship values and their relationship to intellectual security from an Islamic perspective among high school students in Makkah," M.A. thesis, College of Education, Umm Al-Qura University, Makkah, 2009.

[24] S. Amara, "The role of college professor in developing citizenship values to meet the challenges of cultural identity: Alexandria University as a model," Future of Arab Education, vol. 64, no. 17, pp. 5-122, 2010.

[25] S. Alshamany and A. Saad, "University students and belonging issues: opportunities and challenges (students of Taibah University as a model)," Journal of Educational Sciences, vol. 20, no. 1, pp. 47-98, 2012.

[26] A. Alahmadi, "Level of the awareness of the educational issues on global citizenship among the students of the colleges of education at Saudi universities," Mission of the Arabian Gulf Journal, vol. 124, no. 33, pp. 201-285, 2012.

[27] T. Garcia, L. Jacott, and A. Rico, "From traditional to cosmopolitan views on citizenship education: a new instrument for evaluation," in Creating Communities: Local, National and Global, P. Cunningham and N. Fretwell, Eds., pp. 528-537, CiCe, London, UK, 2012.

[28] K. N. Radwan, M. S. Al-Zboon, and M. S. AlZboon, "Role of educational mediain promoting the values of citizenship among students of secondary schoolsin zarqa education directorate II from view point of their teachers," Modern Applied Science, vol. 12, no. 3, pp. 23-34, 2018.

[29] National Center for Improving Science Education, 2016, Developing Scientific Values. Retrieved from http://www. wested.org/project/nationalcenter.

[30] I. Alqahtany, "Scientific values implied in the book of physics of the third grade high school students in Saudi Arabia," M.A. thesis, King Saud University, Riyadh, 2012.

[31] H. R. Shah and L. R. Martinez, "Current approaches in implementing citizen science in the classroom," Journal of Microbiology \& Biology Education, vol. 17, no. 1, pp. 17-22, 2016.

[32] A. Musa, M. Al-Habshi, M. Fathi, and M. Abdeslam, "Citizenship values among university students in the light of the challenges of knowledge society: a field study," Journal of Reading and Literacy, vol. 167, pp. 253-275, 2015.

[33] H. Ali, "Quality management of curricula in citizenship development: a required criterion," in The Fourteenth Scientific Conference Scientific Education and Standards: Theory and Practice, pp. 69-87, The Egyptian Society of Scientific Education, Ismailia, 2010.

[34] A. Elsayed and T. Ismail, "The role of university in raising the awareness of students of the principles of citizenship as an approach imposed by contemporary global challenges," Journal of Educational and Psychological Studies-Zagazig University, vol. 66, no. 2, pp. 1-136, 2010.

[35] G. Newman, A. Wiggins, A. Crall, E. Graham, S. Newman, and K. Crowston, "The future of citizen science: emerging technologies and shifting paradigms," Frontiers in Ecology and the Environment, vol. 10, no. 6, pp. 90-285, 2012.

[36] A. Alotoum, A. Aljarrah, and M. Bishara, Development of Thinking Skills: Theoretical Models and Practical Applications, Dar Almasera, Amman, 2014.

[37] J. Saada, Teaching Thinking Skills: Hundreds of Practical Examples, Dar Alshorouq, Amman, Jordan, 2011.
[38] A. Alsaadani, T. Ouda, and A. Abdelrahman, Introduction to Scientific Research, Dar Alketab Alhadeeth, Cairo, 2010.

[39] M. Taha and S. Sultan, "The effectiveness of the constructive learning model in modifying misconceptions about semantic web and promoting curiosity among the students of the College of Education," Arab Studies on Education and Psychology, vol. 28, pp. 15-72, 2015.

[40] F. Jerwan, Thinking Education: Concepts and Applications, Dar Alfikr, Amman, 2010.

[41] H. Zayton, Development of Thinking Skills: A Prospective View on Self-Development, Sawlatia Press, Jeddah, 2010.

[42] S. Alaskhqar, "The impact of using argument-based investigation on the development of ambition in science among the third year preparatory students," Journal of Scientific Education, vol. 17, pp. 73-120, 2014.

[43] A. Hamida, "A proposed design in history to develop the values of tolerance and accepting others," in the International Conference of the Educational Society for Social Studies: Tolerance and Accepting Others, pp. 11098-11160, The Educational Society for Social Studies, Cairo, 2017.

[44] A. Salem and F. Alymani, "Decision-making and relation to emotional intelligence among educational leaders in the light of some demographic variables," Journal of Educational Sciences, vol. 22, no. 3, pp. 533-566, 2014.

[45] A. Ombosaidy, "Impact of using ethical analysis approach on developing the skills of decision-making and academic achievement in biology among the twelfth grade students," Jordan Journal of Educational Sciences, vol. 14, no. 2, pp. 71-83, 2018.

[46] J. Sullins, "Rights and computer ethics," in The Cambridge Handbook of Information and Computer Ethics, L. Floridi, Ed., pp. 116-132, Cambridge University Press, Cambridge, 2010.

[47] E. Sarno, "Geography and citizenship education: migrations and pathways of educational research," Review of International Geographical Education Online $\odot$ RIGEO, vol. 1, no. 1, 2011.

[48] C. Black, "A procedure for initial evaluation and analysis of linear programs," Innovations in Education and Training International, vol. 2, no. 3, pp. 97-101, 1966. 